\title{
ウェーブレットを利用したはく離の予測と制御
}

\section{Prediction of Flow Separation by Wavelet Transform}

\author{
O正 石川 仁（東理大工） 正 山田俊輔（東理大工） \\ 谷合哲弥（東理大院）
}

Hitoshi ISHIKAWA, Department of Engineering, Tokyo University of Science Shunsuke YAMADA, Department of Engineering, Tokyo University of Science Tetsuya TANIAI, Graduate School of Engineering, Tokyo University of Science

\begin{abstract}
Wavelet analysis was applied to the prediction of flow separation from airfoil. Velocity fluctuations on the surface of the NACA631-012 airfoil at the attack angle of 5 degree were measured by a glue-on type hot-film probe in various chord positions. Morlet wavelet has the advantage to educe unsteady fluctuation over other signal analyses. The coefficient of the Morlet wavelet showed the change of the wavelet scale related to the precursor signal of flow separation. The result suggested that the wavelet analysis was a possible approach to predict and control of flow separation.
\end{abstract}

\section{Key Words: Prediction, Flow separation, Airfoil, Hot-film probe, Fluctuation signal}

1. はじめに

翼や管路コーナ一部からのはく離は, 効率低下や騒音, 振動 などを引き起こす原因となっている. はく離の抑制法については, ボルテックスジェネレータやジェットの吹き出し，吸い込みなど， 受動・能動制御の如何に関わらず様々な提案がなされているが, より効率良く,より小さなエネルギーではく離を制御するには, は く離の開始前，あるいは，はく離が始まってすぐに制御を行うの が良い.その実現のためには速度や圧力の変動波形からはく離 の前兆をなんらかの形で捉える必要がある. 西沢らは, 翼前縁に 設置したセンサーから, 壁面せん断応力の変化を捉えることで, 翼のはく離の制御を行っている ${ }^{(1)}$. また, 望月らは可変ディフュー ザの可動壁面上の圧力変動波形から，はく離の前兆信号を抽出 することを試みている(2).

はく離開始の特徵を含んだ変動波形は非定常であると予想さ れるので, その解析には非定常解析に有効な信号処理法が適 当である. ウェーブレット変換は, 周波数情報に併せ, 時間軸情 報も抽出可能な, 非定常信号を捉えるのに有効な信号処理法で ある. 石川らは, このウェーブレット変換を, 円柱後流の速度変動 波形解析に用い, 後流中の渦構造に内在する非定常な低周波 数変調の解析を行っている( ${ }^{(3)}$.

本研究の目的は, 流れの中に置かれた翼の表面に, 薄型の 熱膜流速プローブを翼弦方向の各位置に貼付して速度変動波 形を測定し，はく離の予測と制御に連続ウェーブレット解析が有 効なことを示すことにある.

\section{2. 実験装置および方法}

図 1 に実験装置および座標系を示す.実験には出口寸法 $250 \mathrm{~mm} \times 250 \mathrm{~mm}$ の吹き出し型風洞を使用した．供試体となる NACA631-012 層流翼は翼弦長 $C=111 \mathrm{~mm}$, 翼幅 $S=230 \mathrm{~mm}$ であ る. 内部は肉厚 $2 \mathrm{~mm}$ の中空構造である. 流れの二次元性確保 のため, 直径 $200 \mathrm{~mm}$, 厚さ $1 \mathrm{~mm}$ の円形の端板を取り付けてある。 翼の正負圧面には静圧孔を設けてあり, 迎角 $\alpha$ を変えられるよう 回転ステージに取り付けて, 風洞出口から $200 \mathrm{~mm}$ 下流に設置し た. 実験は主流流速 $U_{\infty}$, 翼弦長 $C$, 動粘性係数 $v$ とし, $\operatorname{Re}\left(=U_{\infty} C / v\right) \doteqdot 98,000$ で行った，迎角 $\alpha=0^{\circ}$ の位置は翼上下面 の静圧が等しくなる角度で判定し, 迎角 $\alpha=0 \sim 20^{\circ}$ の範囲で実験 を行った.ここでは $\alpha=5^{\circ}$ の結果だけについて述べる.

貼付型熱膜流速プローブ (DANTEC製55R47) は, ボリイミド 製フィルムにニッケルを蒸着した単線のセンサーで, 翼表面から センサーまでの高さは $0.5 \mu \mathrm{m}$ である. 翼表面の $y / S=0.50$ 上, $x / C=0.1,0.4,0.7,0.8$ おび 0.9 のつの位置に糊で貼り付けた。

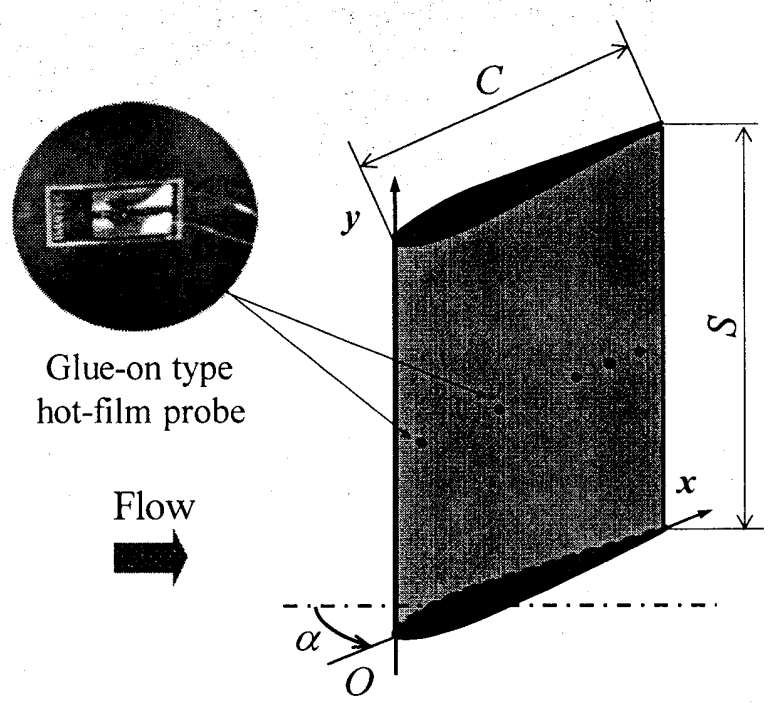

Fig. 1 Experimental setup. NACA-631-012 airfoil and glue-on type hot-film probe.

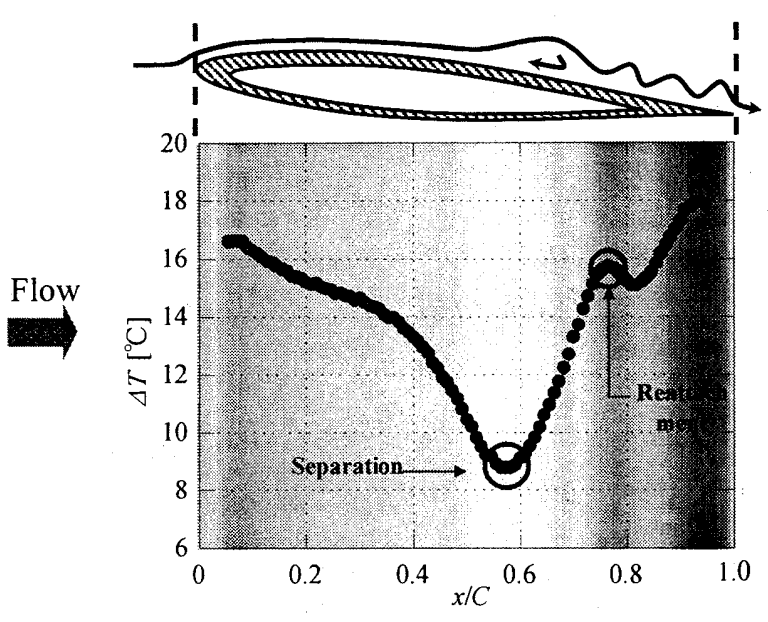

Fig. 2 Temperature difference distribution analyzed by thermal image on the surface of airfoil ${ }^{(4)}$. 


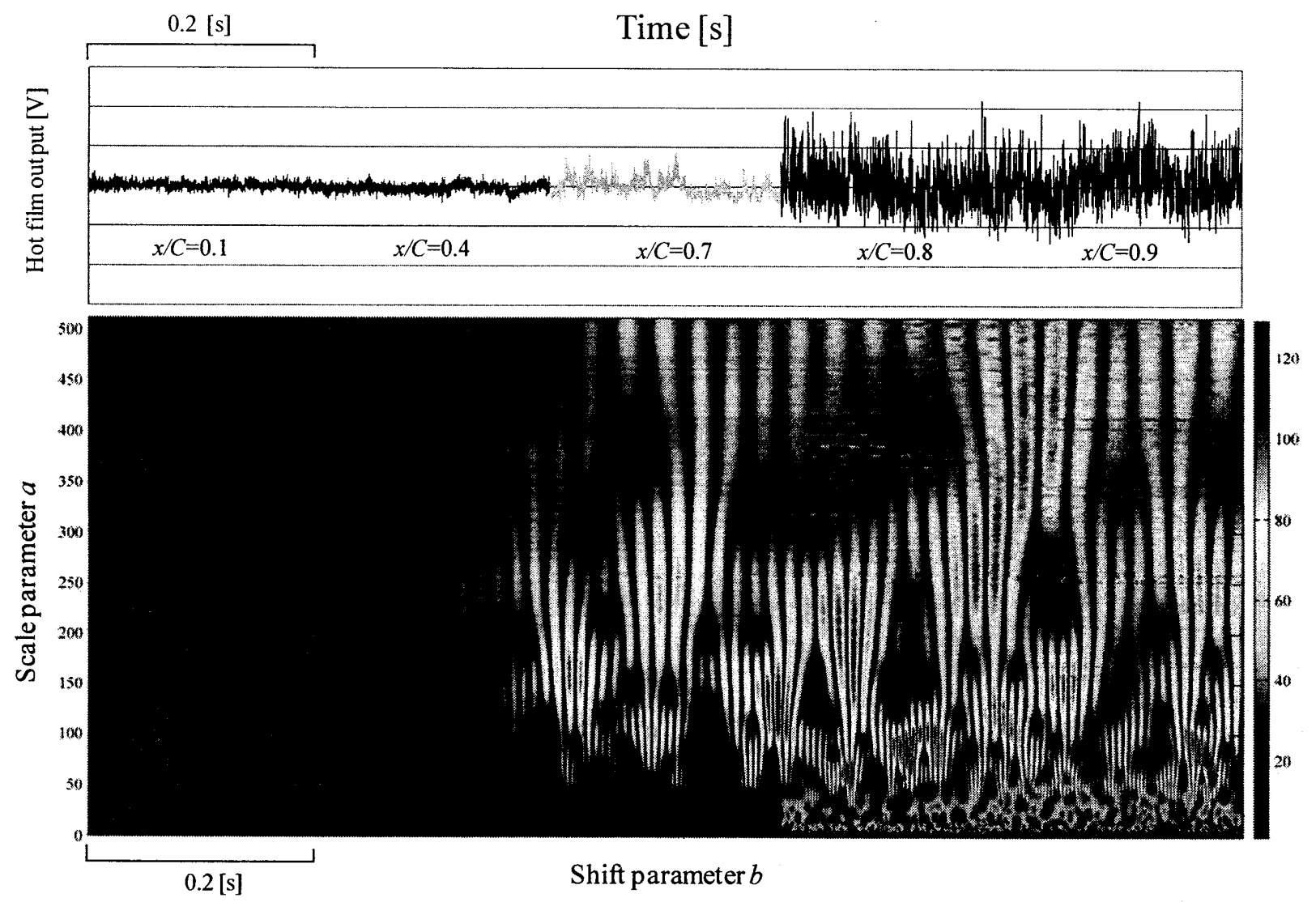

Fig. 3 Velocity fluctuations on the surface of airfoil ( $\alpha=5 \mathrm{deg}$ ) and the morlet wavelet coefficient.

これを定温度型流速計で動作させ, 得られるブリッジ出力の変動 から, 翼表面の速度変動波形を測定した. サンプリングは $10 \mathrm{KHz}$ で行った.

\section{3. 連続ウェーブレット変換}

速度変動波形の解析を行う連続ウェーブレットのマザー ウェーブレットには, Morlet ウェーブレットの実数部を使用 した. Morlet ウェーブレットは次式で定義される.

$$
\psi(x)=\exp \left(-x^{2} / 2\right) \cos 5 x
$$

石川らによる乱流カルマン渦列の解析にも, この Morlet ウェーブレットが用いられている.

\section{4. 実験結果および考察}

まず翼表面の流れの様子を調べるため, 赤外線カメラによる 差分熱画像撮影を事前に行った. その結果を図 3 に示す.この 画像は翼表面をあらかじめ一様に加熱した後, 通風を開始し， 翼面が冷やされる様子を撮影したものである. 実験の詳細につ いては引用文献(4)を参考にされたい.一般に, はく離点での熱 伝達率は極小に, 再付着点での熱伝達率は極大になる性質が あることから ${ }^{(5)}$, 翼表面のはく離の様子をこのような画像から判定 することができる. 図中の黒点は $y / S=0.50$ の位置での温度差 $\Delta T$ であり,これから $x / C=0.1$ が層流, $x / C=0.4$ がはく離泡の直前, $x / C=0.7$ が再付着点前, $x / C=0.8$ が再付着点後, および $x / C=0.9$ が乱流の状態にあることが予想される。

上記をふまえ, 図 3 に各 $x / C$ の位置で測定された熱膜流速 プローブによる速度変動波形に対し, Morlet ウエーブレット解析 を行った結果を示す. 図の上部には生の速度変動波形を, 下部 にはウェーブレット係数の時間ースケール情報を時間軸に対応
させて示してある. 各速度変動波形は時間平均のバイアス分を 差し引いてあること, また同時測定されたものでないことに注意さ れたい. まず変動波形を見ると, 翼後縁に近づくにつれ, 変動の 振幅が大きくなることがわかる. また, $x / C=0.7$ 以降では, 低周波 数のうねり成分が重盢するようになる. Morlet ウェーブレット 解析の結果では, 速度波形に含まれる変動成分の大きさに一致 するスケールに, ウェーブレット係数の高い值が非定常に現れる 様子が観察できる. とくに再付着点前の $x / C=0.7$ の結果でその 傾向が顕著になる．また，係数の高い值が時間経過と共に大 きなスケールへ連続的にシフトする様子も見られる. 大規模 なはく離は, 再付着点後に起こると予想されるので, この ウェーブレット係数の変化をはく離の前兆信号として利用 すれば, 効果的なはく離制御を行えると期待される.

\section{5.おわりに}

本研究では, 翼表面に貼付した熱膜流速プローブによって 測定した速度変動波形に対し連続ウェーブレット解析を 行った. ウェーブレット係数の変化がはく離の予測に適応可 能である可能性を示した.

\section{引用文献}

(1)西沢ら, 翼周りの剥離流に関するスマート制御, 日本流 体力学会誌「ながれ」, 25(4)(2006), pp.111-118

(2)望月ら, はく離の前兆, 機論，67-661，B (2001), pp.2226-2233

(3)石川ら, 乱流カルマン渦列の低周波数変調, 機論, 62-598, B(1996), pp.2180-2186

(4)谷合ら, 熱画像解析による翼表面流れのはく離検出, 可 視化情報, Vol.29, No.2, (2009), pp.137-140

(5)森康夫, 土方邦夫, 流れと熱の工学 II , 共立出版, (1977). 